\title{
TRAINING AS STRATEGY FOR SCHOOL SELF-EVALUATION CAPACITY BUILDING
}

\author{
Mateja Brejc ${ }^{*}$ \\ Klemen Sirok ${ }^{* *}$ \\ Andrej Koren ${ }^{* * *}$
}

Received: 22. 6. 2018

Preliminary communication

Accepted: 26. 3. 2019

UDC 371.3(497.4)

DOI https://doi.org/10.30924/mjcmi.24.si.5

\begin{abstract}
The aim of the paper is to discuss the importance of school (self-) evaluation capacity building within quality assurance system in education in Slovenia. The research is focused on self-evaluation training program in 245 educational institutions. The results demonstrate its importance and pinpoints several challenges, i.e.: "how to build organizational (leaders') evaluation capacity", "learning transfer in practice", and "how to choose among various evaluation capacity building strategies". Building upon
\end{abstract}

\section{INTRODUCTION}

Self-evaluation is, in a way, recognized as one of the central, universal instruments of quality assurance (QA) in education and is increasingly gaining importance. Many countries are reinforcing the evaluation function within their educational systems in order to improve quality and establish evidence-based educational policy and practice (Brejc, 2014; Brejc et al., 2011; Earl \& Katz, 2006; Kellaghan \& Stufflebeam, empirical findings, the paper suggests that the training as a sole strategy for capacity building does not suffice in the competitive, quality-driven educational context. Correspondingly, the model of self-evaluation capacity building for schools is presented and discussed.

Keywords: capacity building strategies, (cascade) training, model, quality assurance in education, school self-evaluation.

2003; OECD, 2013; Scheerens, Glas, \& Thomas, 2003; Scriven, 2003, European Commission, 2017; Schleicher, 2018). The emphasis on the evaluation function stems from a premise that school autonomy and accountability for improvement lead to better responsiveness in the face of local and global demands placed on teachers, their schools and school systems. This strengthening of the evaluation function often coincides with the implementation of education

\footnotetext{
* Mateja Brejc, PhD, assistant professor, National School for Leadership in Education, Ljubljana, Slovenia, E-mail: mateja.brejc@solazaravnatelje.si

${ }^{* *}$ Klemen Širok, PhD, associate professor, University of Primorska, Faculty of Management, Koper, Slovenia, E-mail: klemen.sirok@fm-kp.si

${ }^{* * *}$ Andrej Koren, PhD, professor, International school for social and business studies, Celje, Slovenia, E-mail: andrej.koren@siol.com
} 
decentralization policies, as the counterbalance to such delegation of decision-making to lower systemic levels can be provided precisely by the reinforcement of the role and significance of evaluations and responsibilities (Scheerens et al., 2003).

Since self-evaluation is recognized as a QA tool and can potentially involve a wide array of stakeholders, it is not enough that it is simply acknowledged as something desirable which should be carried out, while the existence of appropriate capabilities in schools is only presupposed. Despite all the international dimensions, transnational trends and related 'soft pressures' as well as national systemic directives, the actual implementation of evaluation, particularly self-evaluation, lies in the hands of schools themselves - or rather their principals and teachers. This is why a clear delineation of their roles and responsibilities within capacity building is of utmost importance, especially since school evaluations are seen as influencing the improvement of school performance and student achievements.

Teachers, however, do not necessarily know how to carry out and use self-evaluation, even though they appear as a unique, large and influential group of professionals with a large stake in evaluation and a long history of being evaluators who assess achievements of their students. According to Kellaghan and Stufflebeam (2003), teachers appear in many roles when it comes to evaluation. In relation to their students, they are the evaluators, but they are also the ones being evaluated by a number of stakeholders, i.e. principals, parents, society or even the international community. Even so, they are not professional evaluators. For selfevaluation to justify its "systemic role/ function" in regard to the improvement of teaching and learning, it is important to emphasize not only the promotion and implementation of a variety of evaluation forms, but also the on-going and systematic capacity building that is necessary for quality and the sustainable use of self-evaluation in schools. The capacity of each school therefore needs to be built systematically, interlinking the teacher, school and school system levels, using different strategies etc.

However, there still seems to be lack of knowledge in the field of evaluation capacity building (hereinafter ECB). SuarezBalcazar and Taylor-Ritz argue that "without a strong science, ECB practice will continue to advance in uneven and unsubstantiated ways that cannot be built upon and further developed and refined. [...] Research on ECB needs to be informed by real issues happening in practice, and practice of ECB needs to be informed by the new knowledge created" (2014, p. 97). The concept and the practice of ECB are still at the inquiry stage, conspicuously showing “ $[\ldots]$ the lack of comprehensive empirical base for various models and a significant focus on approaches and methods for tackling capacity building with less attention being paid to what the latter comprises" (Nielsen, Lemire, \& Skov, 2011, pp. 324-325). Also missing is a more homogenous definition of what evaluation capacity is. Naccarella et al. (2007) therefore warn about the consequences of a diverse conceptualization of capacity, which can in turn lead to a multitude of views on how to build capacity. Additionally, Wandersman (2014, p. 105) cautions against the high level of variability: "Training and technical assistance for evaluation vary greatly in quality, $[\ldots]$ And in all justice, we must admit that the quality and usefulness of evaluation that the profession produces varies disgracefully." Moreover, as Preskill claims (2014, pp. 117-118), there are currently four challenges concerning ECB, i.e.: engaging foundations and non-profit staff in ECB efforts; building organization leaders' evaluation 
capacity; focusing on learning transfer; and evaluating ECB activities.

\subsection{Evaluation capacity building and its strategies}

ECB is still a relatively new concept in the field of evaluation. One can look at ECB from the viewpoint of individual, organization or system. It can be defined as one of the main elements of quality assurance at the organizational and system levels. The aim and goals of ECB are largely linked to a defined role of evaluation and can therefore be used as a management tool in organization, a research tool for understanding activities in society or as an accountability tool (Carman \& Fredericks, 2010; Compton, Baizerman, \& Hueftle Stockdill, 2002; Mayne, Divorski, \& Lemaire, 1999). ECB is "intentional work on the organization as a system and on its structure, culture and everyday practices, with the intent to create and sustain environment for professional expert program evaluation and its uses" (Compton et al., 2002, pp. 11-12). It is about "the extent to which an organization has the necessary resources and motivation to conduct, analyze, and use evaluations" (Gibbs, Napp, Jolly, Westover, \& Uhl, 2002, p. 261). However: "Evaluation capacity-building entails not only developing the expertise needed to undertake robust and useful evaluations; it also involves creating and sustaining a market for that expertise by promoting an organizational culture in which evaluation is a routine part of 'the way we do things around here"” Beere (2005, p. 41).

In their literature review on ECB, Labin, Duffy, Meyers, Wandersman and Lesesne (2012, p. 18) establish that "ECB efforts have a relatively common set of principles and strategies and have achieved some short-term and intermediate-term outcomes at both the individual and organizational levels. In spite of the variation in the narrative reporting of $\mathrm{ECB}$, there is a high degree of consistency between the concepts in the theoretical literature and those found in the empirical literature." Various models (Cousins, Goh, Clark, \& Lee, 2004; Labin et al., 2012; Nielsen et al., 2011; Preskill \& Boyle, 2008; Taylor-Powell \& Boyd, 2008; Volkov \& King, 2005) therefore describe ECB as a process, but it can be also viewed from the perspective of results. Within the framework of the process, there are several approaches and strategies to ECB, such as training, technical assistance, mentorship, etc. ECB results manifest themselves at the level of organization (e.g. as the embeddedness of evaluation in its work) as well as at the level of individuals within the organization (e.g. as knowledge, skills, attitude).

Evaluation capacity can be built in different ways, while it remains important that this building is flexible and contextoriented. Compton et al. (2002, p. 8) argue that ECB is context dependent; if and how ECB is conducted, depends on the reality and situation of each individual organization. The overview of literature and existing models, therefore, show a wide array of ECB approaches, methods and strategies for evaluation to become a routine, everyday practice, as well as a nationally and internationally recognized process. In general, strategies can be implemented in different ways (training, technical assistance, cooperation in evaluation etc.), oriented towards individuals or the organizational level, and rise from various areas (Labin et al., 2012, p. 318). In our opinion, it is important that there are a multitude of methods and strategies underpinning the implementation of ECB in practice, as the organizations and their individuals operate at different knowledge and skill levels, and it would prove counterproductive to approach each of them in the same way. 


\subsection{Training as a strategy for School Self-Evaluation Capacity Building (sECB): The case of Slovenia}

We defined the sECB of schools as the process of a) acquiring and/or improving the knowledge of, skills for and the attitudes of teachers and principals towards self-evaluation; b) establishing institutional frameworks and structures for successful and sustainable self-evaluation implementation aimed at ensuring quality work; c) designing systemic directions, requirements and support for schools as they implement self-evaluation. This definition implies that teachers, principals and the school system are all responsible for capacity building.

In this context, the development of a national QA system, which began as a project in 2008, (Brejc \& Koren, 2011b) primarily focuses on self-evaluation and partly also on the sECB. Within the project, representing the narrower context of our research, different activities have taken place, which belong to the framework of strategies for school sECB (Brejc, 2011a; Brejc \& Koren, 2011b). In short, various (personal and group) approaches and strategies have been used, targeting either the individual or organizational levels. Certain strategies (such as trainings or technical support) have been employed directly, while others (such as establishing communities of practice) have been implemented indirectly through exercising 'primary' strategies.

Among these strategies, the greatest emphasis is placed on training, which also involves the most participants and schools. Training, formal or informal, is in fact only one of possible ECB strategies (Preskill \& Boyle, 2008; Taylor-Powell \& Boyd,

Table 1 Strategies of school sECB in the emerging QA system in Slovenia

\begin{tabular}{|l|l|}
\hline Formal training & $\begin{array}{l}\text { Self-evaluation courses (e.g. SE Training) } \\
\text { One- or two-day workshops on self-evaluation } \\
\text { External evaluation courses }\end{array}$ \\
\hline Field protocols & $\begin{array}{l}\text { Guidelines for self-evaluation reports } \\
\text { Handbook for external evaluators and the organizations under evaluation, } \\
\text { with emphasis on the assessment of self-evaluation implementation in } \\
\text { schools } \\
\text { Protocol for self-evaluation implementation }\end{array}$ \\
\hline $\begin{array}{l}\text { Written materials } \\
\text { and access to self- } \\
\text { evaluation resources }\end{array}$ & $\begin{array}{l}\text { Monographs } \\
\text { Articles } \\
\text { Special materials for training participants } \\
\text { School self-evaluation reports } \\
\text { Various websites offering information on quality and self-evaluation }\end{array}$ \\
\hline $\begin{array}{l}\text { Building } \\
\text { communities of } \\
\text { practice }\end{array}$ & $\begin{array}{l}\text { Peer learning, sharing practical experience, peer examination, group } \\
\text { problem-solving, peer support, consultative evaluation group etc. of: } \\
\text { Self-evaluation teams (at formal training sessions) } \\
\text { Teachers in schools (as part of interim activities within formal training and } \\
\text { self-evaluation processes in schools) }\end{array}$ \\
\hline $\begin{array}{l}\text { Technical assistance/ } \\
\text { external professional } \\
\text { support }\end{array}$ & $\begin{array}{l}\text { Individual consultations (e.g. advice to individual schools about drafting } \\
\text { improvement plans, providing feedback on self-evaluation reports) } \\
\text { Implementation of workshops and meetings in schools }\end{array}$ \\
\hline
\end{tabular}

Note. Adapted from Brejc (2014). 
2008) but often equated with the concept of ECB itself (Eade, 2007) or that of professional development in general (Guskey, 2000; Kirkpatrick \& Kirkpatrick, 2007). "It is the most common form of professional development and the one with which educators have the most experience" (Guskey, 2000, p. 22). It is the most (cost-)effective strategy for the exchange of ideas and information among a greater number of participants. On the other hand, according to Guskey (2000, p. 23), the biggest shortcoming of training is that "it offers few opportunities for choice or individualization. Hence, it may not be appropriate for the varied levels of educators' skills and expertise. Training sessions also must be extended, appropriately spaced, or supplemented with additional follow-up activities to provide the feedback and coaching necessary for the successful implementation of new ideas."

\subsection{The training program for school self-evaluation in Slovenia}

The training program for school selfevaluation in Slovenia (hereinafter SE Training), was selected as a case study, because: (a) it included a great number of participants (principals and teachers) or schools, namely 12,954 leadership or professional staff from 243 kindergartens, primary or secondary schools; (b) it has been, in our opinion, the most sustainable program; (c) it has been the most directly focused on school sECB at the individual level.

Given the allotted time and the number of participating schools and participants for the SE Training, it was decided that a cascade approach to training is to be undertaken (Hayes, 2000; Wedell, 2005), "a strategy often adopted to introduce major innovations into educational systems" (Hayes, 2000, p. 137). The SE Training was conducted at two cascade levels, i.e. (1) the level of self-evaluation teams and (2) the level of teaching staff within each school. The SE Training takes 18 months and is designed as a combination of workshops (direct contact hours) and interim activities (professional discussions among teaching staff, within certain fields or groups, interim activities of individual teachers, etc.), which take place between individual workshops at the level of individual participants (Brejc \& Savarin, 2011).

Workshops are intended for "putting the discussed knowledge and approaches directly into practice" (Brejc \& Savarin, 2011 , p. 25). By means of conducting workshops in schools it is possible to tailor these workshops in terms of time and contents, but still within the agreed framework. After each workshop at a given school, its selfevaluation team members, in their role of self-evaluation coaches, reflect on the implementation, and submit a short standardized report assessing the various aspects of implementation (e.g. the difficulty level of workshop preparations and realization, teachers' motivation before and after the workshop) and content (e.g. agreements or plans for future work at the school level).

Level 1. The SE Training topics are organized in a way that reflects stages in the process of planning, self-evaluation and reporting in schools.

Since the SE Training is currently viewed as the main school sECB strategy, the empirical section of the paper will examine the contribution of the SE Training to sECB in participating schools. The main research question aims to examine how building the capacity for self-evaluation by using training as a strategy is reflected in the practice of selected schools in Slovenia. Based on research findings the sECB model for schools is presented. Next, we present the 
research methodology, where research design, research sample, operationalizations, data analysis and research limitations are presented.

\section{METHODOLOGY}

\subsection{Research design}

Since the research topic here concerns the effects of the SE Training, our research design also draws upon Kirkpatrick's training evaluation model (Chyung, 2008; Guskey, 2000; Kirkpatrick \& Kirkpatrick, 2007), which defines four levels of training effectiveness, i.e. Reaction, Learning, Behavior, and Results. Kirkpatrick's design for evaluating training effectiveness fits our purpose for two reasons. Firstly, the SE Training, which will be evaluated from the perspective of $\mathrm{SECB}$, is aimed at training entire teaching staffs for the implementation and use of sustainable, quality self-evaluation in schools. From this perspective, it is not only the Reaction to training and individual Learning as a result of that training that are important. It is of utmost importance that certain work-related Behavior changes and that the Results also are evident at the organizational level, as this self-evaluation is defined as organizational and involves all teachers at any given school. Secondly, because this SE Training was carried out for the first time, a more exhaustive evaluation, including that of all four levels of effectiveness, provides further relevant information of our SE Training, which is also the fundamental strategy of school sECB in the development of the QA system.

\subsection{Sample}

Since we are interested in research findings at both, the individual and school level, and because the SE Training used a cascade system, our survey research was carried out in the form of a paper-and-pencil questionnaire. Systematic sampling was designed For the research (Guest \& Mitchell, 2013, p. 55; Vogt, Gardner, \& Haeffele, 2012, p. 124) among the population of participant principals $(\mathrm{N}=71,100 \%$ of the population) and team members $(\mathrm{N}=141,100 \%$ of the population), as well as on the sample of participant teachers $(\mathrm{N}=1024,30 \%$ of the population). Out of the 1236 questionnaires sent, 1145 or $92.6 \%$ were completed and received.

\subsection{Operationalization}

Following variables that enable assessing ECB were explored:

- School self-evaluation capacity (hereinafter sEC),

- School sECB

- School level results.

First we assess the initial sEC, then the difference which appears as a result of the SE Training; this is defined as SECB. Due to the general lack of empirical, especially quantitative ECB studies (Labin et al., 2012) we decided to develop the operationalization of $\mathrm{SEC}$ and $\mathrm{SECB}$ variables as well as school level results on our own.

\section{- School self-evaluation capacity}

SSEC is something that participants had already developed, but it was being further built through training. We defined it as the average of the sum of knowledge scores average, ability scores average and SE scores average of every participant at the end of the SE Training.

\section{- School Self-Evaluation Capacity Building (sECB)}

The sECB variable measures the increase of knowledge and skills for selfevaluation implementation and is defined as 
the average of sum of differences, which is shown for the individual training participant as knowledge and skill before and after the SE Training. The state of variables is measured before and after the training by means of a questionnaire at one point in time.

\section{- School level results}

The range of changes in schools' work has been determined on the basis of planned competencies and the fundamental elements of the SE Training design (Brejc, 2011a; Brejc \& Koren, 2011b). At the organizational level, the results of the sECB can, therefore, manifest themselves in a more systematic monitoring and evaluation of one's own work, a more frequent exchange of good practice, the presence of evaluative thinking, an increase in the frequency of professional discussions regarding improvements and self-evaluation implementation, a more extensive use of data and making data-based decisions, the use of self-evaluation for improvement planning, a greater motivation of staff for improvement implementation, accepting responsibility for school performance quality, etc.

All variables of interest are, in their essence, latent variables - difficult to be observed directly. One of the possible ways of observation entails measuring the respondents' opinions using the 6-point bipolar Likert scale. It was used to measure the presence or development of the observed concept dimension. This enabled us to present the respondents with a wide enough range of possible grades, while requiring their opinions to be expressed.

\subsection{Data analysis}

Relationships between variables were analysed through bivariate statistical analysis, for which we used Pearson's and Spearman's correlation coefficients to determine the correlations between variables, taking into consideration the causality interpretation guidelines from Field (2005, pp. 127-128).

\subsection{Research limitations-research validity and reliability measures}

We remain aware that we have not explicitly investigated the transfer of knowledge and skills into practice - an important indicator from the perspective of sECB. We were already partly limited by the means and time allotted to data gathering. As the research was carried out at the end of training, the participants were evaluating their knowledge and skills they had before and after finishing the training. We are also conscious of the fact that the internal validity of the questionnaire has not been systematically examined. It is true, however, that in the process of questionnaire development, we used face validity and expert validity, which were accompanied by consistency in the process of operationalization.

\subsection{Results}

The evidence showing that the sECB has an overall impact in schools is presented next. The findings on determined participants' sEC are conveyed, together with those on participants' $\mathrm{sECB}$ at the school level. The second part of the analysis reveals a positive correlation among variables concerning training and the sECB, which speaks in favor of the SE Training as a suitable ECB strategy.

\subsection{Learning: Improved knowledge and skills}

Upon completion of the SE Training, its participants have shown better knowledge and skills than at the beginning. The distributions of dependent variables that convey the differences both in knowledge and skills show that all training participants improved their knowledge and skills 
for implementing improvements and selfevaluation, on average by 1.15 points for knowledge on the 6-point scale (St. Dev. $=0.77, \mathrm{~N}=1000$ ), and by 1.18 points for skills (St. Dev. $=0,79, \mathrm{~N}=994)$. The biggest improvement in knowledge and skills was revealed among team members (Mean $=1.8$, St. Dev. $=0.73, \mathrm{~N}=108$ ), slightly lesser among principals (Mean $=1.5$, St. Dev. $=0.74, \mathrm{~N}=54)$, and even lesser among teachers $($ Mean $=1.1$, St. Dev. $=$ $0.68, \mathrm{~N}=770$ ). However, all of them testified the improvement surpassing one degree on the scale.

Upon training completion, all participants show on average a mostly positive attitude towards self-evaluation (Mean = 4.8, St. Dev. $=0.69, \mathrm{~N}=1084)$, especially principals $($ Mean $=5.1$, St. Dev. $=0.46, \mathrm{~N}$ $=59)$ and team members $($ Mean $=5.0$, St. Dev. $=0.53, \mathrm{~N}=125)$, teachers just a little less $($ Mean $=4.8$, St. Dev. $=0.71, \mathrm{~N}=900)$.

\subsection{Changes in work-related behavior}

While learning is undoubtedly important, it is paramount that the studied topics and approaches are also put into practice through individual work, which was in fact accomplished by a great majority of principals and team members participating in the SE Training. A qualitative analysis of results to the question "Have you changed anything in your leadership and other work because of your participation in the SE Training?" where "Yes" or "No" were required as replies, shows that almost $86 \%$ of principals and team members changed their way of conducting leadership or other work as a consequence of their participation in the SE Training. Answers to the additional open question inquiring what had been changed were provided by 56 (of 64) principals and 105 (of 132) team members. Most of the written replies can be classified as belonging to one of the following content categories:

- Planning (principals and team members);

- Monitoring and evaluation (principals and team members);

- Cooperation or team work (team members);

- Collaborative leadership, task delegation, integration (principals).

\subsection{School level results}

Results show that, according to participants' opinion, their participation in the SE Training also contributed to change in operation at the school level. There is no difference between the opinions of principals, that of team members and teachers respectively, which tells us that the perception of change within schools is, more or less, similar for everyone. A majority of training participants agree that a certain degree of change took place at the school level directly, because of their involvement in the SE Training. They graded this with the average grade of 4.2 on the 6-point scale. Also, a low standard deviation is important (St. Dev. $=0.36, \mathrm{~N}=1162$ ), which testifies a relative uniformity among all training participants in their perception of changes made. The distribution of variable values is close to the normal distribution (Skewness $=0.136$, Kurtosis $=0.035)$. A more detailed overview of results reveals the highest level of agreement among participants ${ }^{1}$, with statements, such as: self-evaluation findings have been used for improvement of planning in school (Mean = 5.3, St. Dev. $=0.69$, $\mathrm{N}=62)$; priorities at the school level are decided on collectively by the teaching staff (Mean = 5.2, St. Dev. $=0.84, \mathrm{~N}=61$ ); our

Data are aggregated at school level. Averages are calculated for different school types. 
school has developed common efforts for quality $($ Mean $=5.0$, St. Dev. $=0.92, \mathrm{~N}=$ 62); our own work is monitored and evaluated more systematically now $($ Mean $=4.9$, St. Dev. $=1.08, \mathrm{~N}=61$ ).

Participants expressed their greatest disagreement with those statements that also emerge as the biggest "weaknesses" of selfevaluation: there is no additional time pressure $($ Mean $=2.4$, St. Dev. $=1.15, \mathrm{~N}=62)$, and no lack of knowledge or skills in data use has surfaced $($ Mean $=2.8$, St. Dev. $=$ $1.4, \mathrm{~N}=62$ ). The agreement was also rated lower for the following statements: selfevaluation is not perceived as extra paperwork $($ Mean $=3.6$, St. Dev. $=1.4, \mathrm{~N}=62$ ) and the possibility of revealing the weaknesses of school and individuals causes no discomfort $($ Mean $=3.6$, St. Dev. $=1.4, \mathrm{~N}$ $=62$ ).

In order to obtain descriptive data at the school level, participants were presented with the following open question: If you wish to point out other effects of the SE Training in your school, you can write them here. Response was provided by 28 (of 64) principals, 33 (of 132) team members and 15 (of 950) teachers. These replies, more or less, confirm the relatively high estimate of change perception and are summarized below. Some of the effects of the SE Training were, thus, described as, e.g... Now there is more collaborative work among teaching staff and consistency in performing additional tasks. As a consequence of workplanning, coworkers meet more often, talk more openly and look for solutions together. What remains is that teachers still show no desire for in-depth collaboration. Once they realized that their work would be evaluated, they only wished to highlight their successes, not the way that had led them to it. Communication among staff has improved, and so have collaboration across subjects and team work. By setting our priority goals, the staff started to work together as a team and gradually became aware that it is only through common efforts that the goal which was set in our improvement plans could be achieved. As the ultimate goal is the same for both the school and the kindergarten, we can be more optimistic about the future results. Interesting and in our opinion telling were those teachers' opinions which were not necessarily positive, even though, as we have already established, there were not many of them. In this vein, some individuals feel it is difficult to come to results successfully, as there is a tendency among teachers to be inconsistent and not follow agreements. As a possible cause for this some suggest, e.g.: There is too much paperwork in the education system. Teachers are running short of time which they could dedicate to teaching. What seems to be important is that everything is precisely recorded and documented, at the expense of teaching quality. Or: Self-evaluation does not improve the quality of my work. If anything, I run out of motivation to take bigger steps for the benefit of students.

\subsection{Training as a suitable sECB strategy}

The SE Training has proved as a suitable sECB strategy since the empirical results show that work changes at the school level have been linked to both, the initial sEC as well as its building. At the school level, self-evaluation capacity is strongly positively correlated with school level results. This is reflected in the value of Pearson's correlation coefficient $(r=0.835$, sig. $=0.000)$. Since the two variables do not indicate normal distribution, the correlation was double-checked by calculating Spearman's correlation coefficient, which showed a slightly lower but still strongly positive correlation between the two 
variables $(\mathrm{rs}=0.774$, sig. $=0.000)$. There is also a positive correlation between the $s E C B$ and the school level results. Here, too, the calculation of correlation coefficients points to a strongly positive correlation $(\mathrm{r}=0.659$, sig. $=0.000)$. As the two variables do not display normal distribution, Spearman's coefficient ( $\mathrm{rs}=0.649$, sig. $=0.000)$ was calculated, in addition to Pearson's, and no significant deviations were found between the two.

\section{CONCLUSIONS}

Based on the theoretical overview and presented empirical findings, it is our conclusion that training is important and, in this specific context, also effective. However, to achieve quality sustainable self-evaluation implementation and use, it is necessary to take a broader view of the ECB. Although training seems like an effective sECB strategy, it does not suffice in a competitive quality-driven educational context. Thus the elements of the sECB model are further presented and discussed.

The SECB model builds on the definition that describes self-evaluation as "the on-going monitoring and final self-assessment of achieving priority goals set for improvements in the field of learning and teaching or in the field of student achievement within a given time-frame, e.g. one school year" (Brejc \& Koren, 2011a, p. 24). The goal of self-evaluation efforts is to improve student achievement, while the fundamental purpose of the sECB efforts can be, in accordance with this goal, defined as conducting and using high quality and sustainable self-evaluation in schools, which we placed in the center of the model (see Figure 1).

System level: QA with self-evaluation required in schools, orientation for selfevaluation implementation, support during self-evaluation implementation.

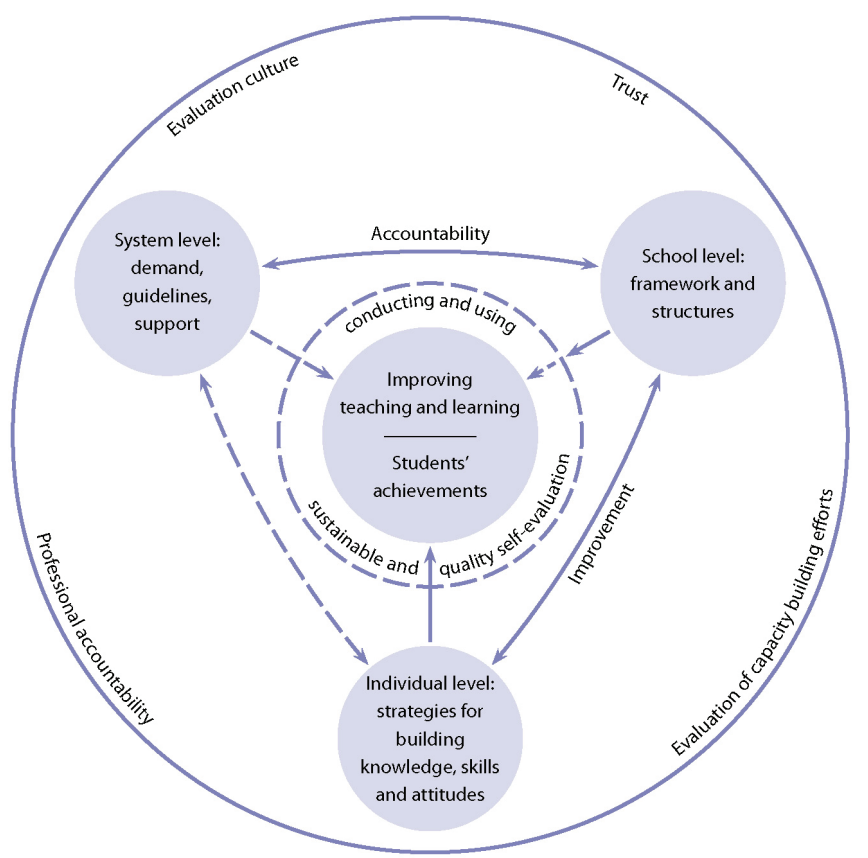

Figure 1. School Self-Evaluation Capacity Building Model 
School level: self-evaluation as school policy action, the integration of self-evaluation in school work, leading self-evaluation, agreement on frameworks and process, planning and systematic self-evaluation implementation, resources for self-evaluation, internal self-evaluation capacity building and organizational learning, cross-organizational collaboration.

Individual level: strategies for building knowledge, skills and attitude towards self-evaluation: the use of national field protocol(s), external professional advice and assistance, collaboration in crossschool networking, participation at formal trainings, the use of in-house school protocol(s), the use of school communication system and its feedback mechanism, encouraging teachers and their participation in school self-evaluations, mentorship, mutual consulting and in-house peer evaluation, participation in professional learning communities at school, the use of accessible resources for self-evaluation, self-education.

The wider framework of capacity building within the proposed model consists of evaluation culture, professional responsibility and trust. When discussing the SECB it is critical to emphasize the importance of evaluation culture, which of course reaches beyond its implications for self-evaluation implementation (quantity), its technical and procedural aspects. "Internal evaluation culture is central to the influence of enquiry in creating and applying useful knowledge" (Owen, 2003, p. 44).

To achieve sustainable, quality selfevaluation implementation in schools, it is important that the ECB is defined at three interconnected levels:

- At the system level (SYSTEM) as a formulation of "demands", policies and support in QA with self-evaluation;
- At the level of organization (SCHOOL) as the setting up of frameworks and structures for self-evaluation implementation;

- At the level of individual (TEACHER) as a process of gaining and/or improving knowledge, skills and attitude towards self-evaluation, which requires different strategies.

The proposed model is the first attempt of its kind trying to systematically define the SECB in the context of the Slovene educational system and schools, though it could prove useful for other national contexts as well, because we have not yet encountered a comparable or school-oriented sEBC model in literature. It is important that the model is regarded as a starting point for further reflection since it draws attention to (1) potential "demands", directions and support in self-evaluation that schools receive at the level of system; (2) frameworks and structures at the level of organization; 3 ) the kind of knowledge, skills, and attitudes that are expected to be adopted and developed by teachers at the level of individuals. It simultaneously offers a basis for the monitoring and evaluation of capacity building at different individual levels separately or together. The constructed model can serve for reflection on the sECB as a comprehensive, systematic but also adaptable process that can function in diverse contexts, taking into account the variability of needs.

At the level of school, the main challenges lie in how to incorporate self-evaluation into the school policy as one of its actions, how to make evaluation meaningful for the purpose of improving student achievement, and how to sustain it. As principals have concluded in the study, it is important for them as leaders to be familiar with and understand self-evaluation, in order to be able to promote it a part of 
improvements in their schools, motivate teachers and ensure its sustainability. Although the general attitude toward selfevaluation is positive in principle, it can be sensed from the experience of working with principals and teachers that self-evaluation implementation can sometimes be perceived as just another project, the main drawbacks being the time its activities take and the extra paperwork it requires.

The greatest challenge at the level of individuals relates to developing self-evaluation knowledge, skills and attitudes - who, when, how, where, etc. In order to establish a complete set of capacity building strategies, the pre-existing capacity and actual

\section{References}

1. Brejc, M. (2014). Krepitev zmožnosti za samoevalvacijo $v$ šolah [Capacity building for self-evaluation in schools]. Kranj, Slovenia: Šola za ravnatelje.

2. Baizerman, M., Compton, D., \& Stockdill, S. H. (2002). New directions for ECB. New Directions for Evaluation, 93, 109-120.

3. Beere, D. (2005). Evaluation capacity-building: A tale of value-adding. Evaluation Journal of Australasia 5(2), 41-47.

4. Brejc, M. (2011a). Usposabljanje za uvedbo sistema ugotavljanja in zagotavljanja kakovosti vzgojnoizobraževalnih organizacij (vrtcev in šol): poročilo o izvedbi 1. cikla usposabljanj [Training for introducing the System of Quality Assurance in educational organizations (kindergartens and schools): Report on implementation of the 1st training cycle]. Kranj, Slovenia: Šola za ravnatelje.

5. Brejc, M. (2011b). Usposabljanje za samoevalvacijo: usposabljanje needs of teachers should be assessed beforehand through a closer observation of self-evaluation in schools. At the level of individuals, it is first important to establish a suitable attitude toward self-evaluation, then nurture, develop and build the relevant knowledge and skills-especially as the participants in our study have concluded that without any additional training, the majority of them would be unable to perform self-evaluation. Naturally, training is probably just one of those capacity building strategies or the types of support that are very important in the initial stage. But, as we were made aware of in the study, it is not and cannot be the only one.

za uvedbo sistema ugotavljanja in zagotavljanja kakovosti vzgojnoizobraževalnih organizacij uKVIZ: predstavitev programa [Training for introducing the System of Quality Assurance in educational organizations uKVIZ: Program presentation]. Kranj, Slovenia: Šola za ravnatelje.

6. Brejc, M., \& Koren, A. (2011a). Zasnova modela samoevalvacije $\mathrm{v}$ sistemu ugotavljanja in zagotavljanja kakovosti [Designing the model of self-evaluation in the System of Quality Assurance]. In M. Brejc, A. Koren, \& M. Zavašnik Arčnik (Eds.), Ugotavljanje in zagotavljenje kakovosti: teorija in praksa uvajanja samoevalvacije $v$ šole in vrtce [Quality assurance: Theory and practice of introducing self-evaluation in schools and kindergartens] (pp. 7-11). Kranj, Slovenia: Šola za ravnatelje.

7. Brejc, M., \& Koren, A. (2011b). Uvajanje samoevalvacije $\mathrm{v}$ šolah in vrtcih kot pristop $\mathrm{h}$ kakovosti na nacionalni ravni [Introducing self-evaluation in schools and kindergartens 
as national quality approach]. In $\mathrm{M}$. Brejc, A. Koren, \& M. Zavašnik Arčnik (Eds.), Ugotavljanje in zagotavljenje kakovosti: teorija in praksa uvajanja samoevalvacije $v$ šole in vrtce [Quality assurance: Theory and practice of introducing self-evaluation in schools and kindergartens] (pp. 13-43). Kranj, Slovenia: Šla za ravnatelje.

8. Brejc, M., \& Koren, A. (2014). Implementing external evaluation in schools: The case of Slovenia. International Journal of Management in Education, 8(4), 374-390.

9. Brejc, M., \& Savarin, A. (2011). Usposabljanje za samoevalvacijo: poročilo o izvedbi 1. cikla [Training for self-evaluation: Report on implementing the 1st training cycle]. In M. Brejc (Ed.), Usposabljanje za uvedbo sistema ugotavljanja in zagotavljanja kakovosti vzgojno-izobraževalnih organizacij (vrtcev in šol): poročilo o izvedbi 1. cikla usposabljanj [Training for introducing the System of Quality Assurance in educational organizations (kindergarten and schools): Report on implementing the 1st training cycle] (pp. 15-42). Kranj, Slovenia: Šola za ravnatelje.

10. Buck, A. (2016). Leadership Matters. How leaders at all levels can create good schools. John Cat Educational LTD.

11. Carman, J., \& Fredericks, K. (2010). Evaluation capacity and nonprofit organizations. American Journal of Evaluation, 31(1), 84-104.

12. Chyung, S. Y. (2008). Foundations of instructional and performance technology. Amherst, MA: HRD.

13. Compton, D. W., Baizerman, M., \& Stockdill, S. H. (2002). The art, craft, and science of evaluation capacity building. San Francisco, CA: Jossey-Bass.

14. Cousins, J. B., Goh, S. C., Clark, S., \& Lee, L. E. (2004). Integrating evaluative inquiry into the organizational culture: A review and synthesis of the knowledge base. Canadian Journal of Program Evaluation, 19, 99-142.

15. DeVellis, R. F. (2003). Scale development: Theory and applications. Thousand Oaks, CA: Sage.

16. Eade, D. (2007). Capacity building: Who builds whose capacity? Development in Practice, 17(4-5), 630-639.

17. Earl, L., Lai, M. K., \& Schildkamp, K. (2012). Data-based decision making in education: Challenges and opportunities. Dordrecht, The Netherlands: Springer.

18. Earl, L., \& Katz, S. (2006). Leading schools in a data-rich world: Harnessing data for school improvement. Thousand Oaks, CA: Corwin.

19. European Commission. (2017). School development and excellent teaching for a great start in life. Brusses: European Commission.

20. Field, A. (2005). Discovering statistics using SPSS (and sex, drugs and rock ' $n$ 'roll). London, England: Sage.

21. Gibbs, D., Napp, D., Jolly, D., Westover, B., \& Uhl, G. (2002). Increasing evaluation capacity within community-based HIV prevention programs. Evaluation and Program Planning, 25(3), 261-269.

22. Guest, G., \& Mitchell, M. L. (2013). Collecting qualitative data: A field manual for applied research. Thousand Oaks, CA: Sage.

23. Guskey, T. R. (2000). Evaluating professional development. Thousand Oaks, CA: Corwin. 
24. Hayes, D. (2000). Cascade training and teachers' professional development. ELT Journal, 54(2), 135-145.

25. Kellaghan, T., \& Stufflebeam, D. L. (2003). International handbook of educational evaluation. Dordrecht, The Netherlands: Kluwer.

26. Kirkpatrick, D. L., \& Kirkpatrick, J. D. (2007). Implementing the four levels: $A$ practical guide for effective evaluation of training programs. San Francisco, CA: Berrett-Koehler Publishers.

27. Labin, S. N., Duffy, J. L., Meyers, D. C., Wandersman, A., \& Lesesne, C. A. (2012). A research synthesis of the evaluation capacity building literature. American Journal of Evaluation, 33(3), 307-338.

28. Mayne, J., Divorski, S., \& Lemaire, D. (1999). Locating evaluation: Anchoring evaluation in the executive or the legislature, or both or elsewhere? In R. Boyle \& D. Lemaire (Eds.), Building evaluation capacity: Lessons from practice (pp. 23-52). New Brunswick, NJ: Transaction.

29. Naccarella, L., Pirkis, J., Kohn, F., Morley, B., Burgess, P., \& Blashki, G. (2007). Building evaluation capacity: Definitional and practical implications from an Australian case study. Evaluation and Program Planning, 30(3), 231-236.

30. Nevo, D. (2001). School evaluation: Internal or external? Studies in Educational Evaluation, 27(2), 95-106.

31. Nielsen, S., Lemire, S., \& Skov, M. (2011). Measuring evaluation capacity: Results and implications of a Danish study. American Journal of Evaluation, 32(3), 324-344.

32. OECD. (2013). Synergies for better learning. Paris, France: OECD.

33. Owen, J. M. (2003). Evaluation culture: A definition and analysis of its development within organisations. Evaluation Journal of Australasia, 3(1), 43-47.

34. Preskill, H. (2014). Now for the hard stuff: Next steps in ECB research and practice. American Journal of Evaluation, 35(1), 116-119.

35. Preskill, H., \& Boyle, S. (2008). A multidisciplinary model of evaluation capacity building. American Journal of Evaluation, 29(4), 443-459.

36. Scheerens, J., Glas, S. A. W., \& Thomas, S. (2003). Educational evaluation, assessment, and monitoring: A systemic approach. Lisse, The Netherlands: Swets \& Zeitlinger.

37. Schildkamp, K. (2007). The utilization of a self-evaluation instrument for primary education. Enschede: University of Twente, Department of Educational Organization and Management.

38. Schleicher, A. (2018). World class: How to build a 21-st-century school system, Strong Performers and Successful Reformers in Education, OECD Publishing, Paris.

39. Scriven, M. (2003). Evaluation theory and metatheory. In T. Kellaghan \& D. L. Stufflebeam (Eds.), International handbook of educational evaluation (pp. 15-30). Dordrecht, The Netherlands: Kluwer.

40. Suarez-Balcazar, Y., \& Taylor-Ritz, T. (2014). Moving from science to practice in evaluation capacity building. American Journal of Evaluation, 35(1), 95-99.

41. Taylor-Powell, E., \& H. Boyd. (2008). Evaluation capacity building in complex organizations. New Directions for Evaluation, 120, 55-69.

42. Vogt, W. P., Gardner, D. C., \& Haeffele, L. M. (2012). When to use what research design. New York, NY: Guilford Press. 
43. Volkov, B., \& King, J. A. (2007). A checklist for building evaluation capacity. Retrieved from http://www. wmich.edu/evalctr/archive_checklists/ ecb.pdf

44. Wandersman, A. (2014). Getting to outcome: An evaluation capacity building example of rationale, science and practice. American Journal of Evaluation, 35(1), 100-106.

45. Wedell, M. (2005). Cascading training down into the classroom: The need for parallel planning. International Journal of Educational Development International Journal of Educational Development, 25(6), 637-651. 


\section{Journal of Contemporary Management Issues}

\section{OBRAZOVANJE KAO STRATEGIJA UNAPREĐENJA KAPACITETA ZA ŠKOLSKU SAMOANALIZU}

\section{Sažetak}

$U$ ovom se radu raspravlja o značaju $k a-$ paciteta za provedbu školske samoanalize, kao čimbenika sustava osiguranja kvalitete u slovenskom obrazovanju. Istraživanje se usmjerava na program obrazovanja za školsku samoanalizu u 245 obrazovnih institucija. Rezultati istraživanja utvrđuju nekoliko ključnih izazova, primjerice: "kako izgraditi kapacitet vođa za evaluaciju", "praktični transfer učenja" te "kako birati između razlicitih strategija izgradnje kapaciteta za evaluaciju”. Na temelju empirijskih rezultata, smatra se da obrazovanje, kada se koristi kao jedina strategija za izgradnju evaluacijskog kapaciteta, nije adekvatno u kompetitivnom obrazovnom kontekstu, kojeg usmjerava predanost kvaliteti. Također se prezentira i raspravlja o modelu izgradnje kapaciteta za školsku samoanalizu.

Ključne riječi: strategije izgradnje kapaciteta, (kaskadno) obrazovanje, model, osiguranje kvaliteta u obrazovanju, školska samoanaliza 